\title{
EFFECT OF ORGANIC MANURE AND SOME MACRO AND MICRO NUTRIENTS ON WHEAT GROWN ON A SAND SOILS I. YIELD POTENTIALITY

\author{
Ali,M.E.*; S.A. Ismail ${ }^{\star \star} ;$ O.H.M. El-Hussieny* and A.M. Abd El-Hafeez ${ }^{\star \star}$ \\ * Dept. of Soils, Fac. of Agric. Benha, Univ. \\ ** Soil, Water and Environment Res. Inst., A.R.C., Egypt.
}

\section{ABSTRACT}

Two field experiments were performed in Village No. 1, West of Samallote, Minia Governorate, Egypt during 2004/2005 and 2005/2006 seasons to study the effect of four levels of farmyard manure, i.e. 0, 10, 20 and 30 metric ton/fed; NPK fertilization doses i.e. (0/0/0), (60/15/24) and (120/30/48) ( $\mathrm{kg} \mathrm{N} / \mathrm{P}_{2} \mathrm{O}_{5} / \mathrm{K}_{2} \mathrm{O} / \mathrm{fed}$.) and methods of $\mathrm{Fe}, \mathrm{Mn}, \mathrm{Zn}$ and $\mathrm{Cu}$ micronutrient application, namely without micronutrients, soil application and foliar spraying on dry weight, grain and straw yields and nutrient use efficiency of wheat Triticum aestivium, (cv Sids 1) under a newly cultivated sand soil conditions.

Dry weight and grains and straw yields showed positive response to application of 30 ton FYM/fed, the use efficiency for N, P and K decreased with increasing organic manure potentially at the highest FYM rate.

Dry weight and grain and straw yields as well as NPK-use efficiency increased as NPK increased to the highest level. The lowest values in P- and K-use efficiency were recorded with the low NPK rate.

Application of micronutrients increased grain and straw yields as well as N, P and $\mathrm{K}$ use efficiency. Foliar spray surpassed soil application on grains and straw yields, but soil application method exerted the highest values of $\mathrm{N}, \mathrm{P}$ and $\mathrm{K}$ use efficiency.

Results recommended that wheat under sand soils should be fertilized with 30 ton FYM/Fed, NPK at rate of $120 \mathrm{~kg} \mathrm{~N}, 30 \mathrm{~kg} \mathrm{P} \mathrm{O}_{5}$ and $48 \mathrm{~kg} \mathrm{~K} 2 \mathrm{O} / \mathrm{fed}$ and micronutrients ( $\mathrm{Fe}, \mathrm{Mn}, \mathrm{Zn}$ and $\mathrm{Cu}$ ) as foliar spraying.

Keywords: Wheat, sand soils, farmyard manure, nitrogen, phosphorus, potassium, micronutrients, use efficiency.

\section{INTRODUCTION}

It is well known in Egypt that the expansion in wheat cultivation through wide sand soil areas is the best solution for curtailing the gab between consumption and production of wheat. However, production of wheat in the sand soil is facing many problems, among them the low organic matter and thus the poor soil fertility.

There is no doubt that the favorable effect of organic manure is sustaining soil fertility through providing crop plants with the essential nutrients as well as improving soil physical properties. Sakr et al. (1992), El-Afandy (1995), El-Ghamry and El-Naggar (2001) and Abd El-Hafeez (2004) showed that dry weight of wheat plants significantly increased by organic manure application. Also, Mowafy (2002), Khalil and Aly (2004) and Ali, Maha (2007) reported that grain and straw yields of wheat positively responded to FYM application.

As for NPK fertilization, many authers noticed the increasing yields of wheat dry weight as well as grain and straw due to increasing application of N, (Balyan, 1992, Atia and Ali, 1998 and Abd El-Maksoud, 2002), P (El-Bana, 2000 and Shrivastava et al., 2003 and K (El-Yamani, 2003 and Galal, 2007). 
Concerning micronutrients many investigators reported that yield of wheat plants responded to micronutrients (Shams El-Din, 1993; Ismail et al., 2006 and Galal, 2007).

The present work aimed to investigate the effect of applied farmyard manure (FYM) and NPK fertilizer and micronutrients application methods (soil and foliar application) on yield of wheat plants grown on sand soils).

\section{MATERIALS AND METHODS}

Two field experiments were performed in Village No. 1, West of Samallote, Minia Goveronorate, Egypt to represent the newly reclaimed sand soil during the winter seasons of 2004/2005 and 2005/2006, to find out the response of wheat (Triticum aestivium L.), cv Sids 1 to four levels of FYM ( 0 , 10, 20 and 30 metric ton/fed), three levels of NPK fertilization 0/0/0, 60/15/24 and $120 / 30 / 48 \mathrm{~kg} \mathrm{~N} / \mathrm{P}_{2} \mathrm{O}_{5} / \mathrm{K}_{2} \mathrm{O} / \mathrm{fed}$, respectively and three treatments of $\mathrm{Fe}$, $\mathrm{Mn}, \mathrm{Zn}$ and $\mathrm{Cu}$ micronutrient application, namely no application and soil and foliar applications. The soil physical and chemical properties of the experiment field (Table, 1) were determined according to Klute (1986) and Page et al. (1982), respectively.

Table (1):Some physical and chemical properties of the experimental soil before planting of wheat in the two growing seasons.

\begin{tabular}{|c|c|c|}
\hline \multirow{2}{*}{ Soil properties } & \multicolumn{2}{|c|}{ Season } \\
\hline & First season & Second season \\
\hline \multicolumn{3}{|l|}{ Particle size distribution\% } \\
\hline Clay (\%) & 10.94 & 11.84 \\
\hline Silt (\%) & 12.75 & 9.35 \\
\hline Sand (\%) & 76.31 & 78.81 \\
\hline Texture grade & Sandy loam & Sandy loam \\
\hline \multicolumn{3}{|l|}{ Chemical properties } \\
\hline $\mathrm{pH}^{*}$ & 8.00 & 7.98 \\
\hline $\mathrm{EC}\left(\mathrm{dS} \mathrm{m} \mathrm{m}^{-1}\right)^{\star *}$ & 1.60 & 1.65 \\
\hline Organic matter (\%) & 0.85 & 0.78 \\
\hline $\mathrm{Ca} \mathrm{CO}_{3}(\%)$ & 4.20 & 3.94 \\
\hline Soluble $\mathrm{Ca}^{2+}$ & 5.62 & 5.67 \\
\hline Soluble $\mathrm{Mg}^{2+}$ & 5.21 & 5.42 \\
\hline Soluble $\mathrm{Na}^{+}$ & 2.57 & 2.90 \\
\hline Soluble $\mathrm{K}^{+}$ & 2.16 & 2.58 \\
\hline Soluble $\mathrm{CO}_{3}{ }^{2-}$ & 0.00 & 0.00 \\
\hline Soluble $\mathrm{HCO}_{3}^{-}$ & 1.95 & 2.29 \\
\hline Soluble $\mathrm{Cl}^{-}$ & 6.89 & 7.29 \\
\hline Soluble $\mathrm{SO}_{4}{ }^{2-}$ & 6.72 & 6.99 \\
\hline Available $\mathrm{N}\left(\mathrm{ug} / \mathrm{g}^{-1}\right)$ & 2.33 & 2.95 \\
\hline Available P $\left(\mathrm{ug} / \mathrm{g}^{-1}\right)$ & 6.12 & 8.01 \\
\hline Available K $\left(\mathrm{ug} / \mathrm{g}^{-1}\right)$ & 7.35 & 9.62 \\
\hline Available Fe $\left(\mathrm{ug} / \mathrm{g}^{-1}\right)$ & 2.39 & 2.13 \\
\hline Available $\mathrm{Mn}\left(\mathrm{ug} / \mathrm{g}^{-1}\right)$ & 1.36 & 1.12 \\
\hline Available $\mathrm{Zn}\left(\mathrm{ug} / \mathrm{g}^{-1}\right)$ & 0.88 & 0.78 \\
\hline Available Cu $\left(\mathrm{ug} / \mathrm{g}^{-1}\right)$ & 0.42 & 0.43 \\
\hline
\end{tabular}

Measured in 1:2.5 soil water suspension.

** Measured in soil paste.

*** Measured in soil paste. 
Farmyard manure was applied before planting. Chemical compositions of the FYM are shown in Table (2). Nitrogen fertilizer was added as ammonium nitrate $(33.5 \% \mathrm{~N})$ at six equal doses, the first was applied before the first irrigation and the others were added before every irrigation latter. Phosphorus and potassium treatments were added before planting as ordinary calcium superphosphate $15.5 \% \quad \mathrm{P}_{2} \mathrm{O}_{5}$ and potassium sulphate $48 \% \mathrm{~K}_{2} \mathrm{O}$, respectively. $\mathrm{Fe}, \mathrm{Mn}, \mathrm{Zn}$ and $\mathrm{Cu}$ micronutrients were added in two ways (1) through soil at $2+4+3+1 \mathrm{~kg}$ (respectively)/fed. (2) through foliar spray at $480+800+560+200 \mathrm{~g}$ (respectively)/fed. Spraying was done twice at $400 \mathrm{~L} /$ fed each time, once 45 days after planting, the other 15 days later. Concentrations of $\mathrm{Fe}, \mathrm{Mn}, \mathrm{Zn}$ and $\mathrm{Cu}$ in the spray solution were $600+1000+700+250 \mathrm{mg}$ (respectively)/L. Micronutrient materials were sulphates of each of $\mathrm{Fe}, \mathrm{Mn}, \mathrm{Zn}$ and $\mathrm{Cu}$. Normal agronomic practices were applied as done for wheat production in by farmers in the region.

\section{Table (2): Chemical composition of FYM.}

\begin{tabular}{|l|c|c|}
\hline \multicolumn{1}{|c|}{ Properties } & $\mathbf{1}^{\text {st }}$ Season & $\mathbf{2}^{\text {nd }}$ Season \\
\hline Organic matter \% & 28.50 & 25.60 \\
\hline Total N\% & 1.68 & 1.42 \\
\hline C/N ratio & $1: 17$ & $1: 18$ \\
\hline Total N \% & 0.62 & 0.56 \\
\hline Total P \% & 0.19 & 0.18 \\
\hline Total K \% & 0.71 & 0.66 \\
\hline Available Fe $\left({\left.\mathrm{ug} / \mathrm{g}^{-1}\right)}^{-1}\right)$ & 5.2 & 6.7 \\
\hline Available $\mathrm{Mn}\left(\mathrm{ug} / \mathrm{g}^{-1}\right)$ & 3.1 & 4.6 \\
\hline Available $\mathrm{Zn}\left(\mathrm{ug} / \mathrm{g}^{-1}\right)$ & 1.8 & 2.0 \\
\hline Available $\mathrm{Cu}\left(\mathrm{ug} / \mathrm{g}^{-1}\right)$ & 0.9 & 0.6 \\
\hline
\end{tabular}

The experiment was designed and executed as a randomized complete block, factorial involving the 3 factors of FYM, NPK and Fe, Mn, Zn and $\mathrm{Cu}$, in 4 replicates. The plot area was $1 / 400$ fed $(3 \times 3.5 \mathrm{~m})$.

Ten plants were randomly taken from each plot at heading stage to determine plant dry weight. At harvest, the plots were hand-harvested to record grain and straw yield. Nitrogen, phosphorus and potassium use efficiency (NUE) were calculated according to Craswell and Godwin (1984) as follows:

\section{Nutrient use efficiency (NUE) $=$ Error}

Where, $\mathrm{F}$ denotes "plants fertilized with the nutrient" and " $\mathrm{C}$ denotes plants not fertilized with the nutrient. The data were subjected to statistical analysis according to Sendecor and Cochran (1980).

\section{Dry weight:}

\section{RESULTS AND DISCUSSION}

Results in Table 3 show the effect of organic manure, NPK fertilization and methods of micronutrients applications on wheat dry weight at 
heading stage. The data revealed that addition of farmyard manure significantly increased the dry weight of wheat plant. The highest increments of dry weight were recorded for the plants which received 30 ton/fed FYM in both seasons. The increase percentage in the first season reached to 19.3, 27.3 and $52.6 \%$ due to application of 10,20 and 30 ton/fed FYM, respectively. The same trend was obtained in the second season. These increases reflect the improvement of fertility status and physical properties caused by FYM application, especially in this sand soil. These results are in harmony with those obtained by El-Ghamry and El-Naggar (2001) and Abd El-Hafeez (2004).

Plants supplied with the highest NPK dose (120/30/48) produced the highest values of wheat dry weight in both growing seasons. This reflects increased growth with increasing levels of NPK, protoplasm which consequently increases dry matter. These results are similar to those obtained by Galal (2007), who found that wheat dry weight significantly responded to NPK fertilization.

Table (3): Dry weight (g/plant) as affected by organic manure, NPK and micro-nutrients application.

\begin{tabular}{|c|c|c|c|c|c|c|c|c|c|}
\hline \multirow{3}{*}{$\begin{array}{c}\text { FYM } \\
(\mathrm{A}) \\
\text { metric } \\
\text { ton/fed }\end{array}$} & \multirow{3}{*}{$\begin{array}{c}\text { Rate of } \\
\mathrm{N} / \mathrm{P}_{2} \mathrm{O}_{5} / \mathrm{K}_{2} \mathrm{O} \\
\text { (kg/fed) } \\
\text { (B) }\end{array}$} & \multicolumn{8}{|c|}{ Micro-nutrients (C) } \\
\hline & & \multicolumn{4}{|c|}{ First season } & \multicolumn{4}{|c|}{ Second season } \\
\hline & & None & $\begin{array}{c}\text { Soil } \\
\text { appli. }\end{array}$ & $\begin{array}{l}\text { Foliar } \\
\text { appli. }\end{array}$ & Mean & None & $\begin{array}{c}\text { Soil } \\
\text { appli. }\end{array}$ & $\begin{array}{l}\text { Foliar } \\
\text { appli. }\end{array}$ & Mean \\
\hline \multirow{3}{*}{0.0} & \multirow{3}{*}{$\begin{array}{c}0.0 \\
60 / 15 / 24 \\
120 / 30 / 48\end{array}$} & 2.56 & 2.76 & 2.63 & 2.65 & 2.38 & 2.44 & 2.57 & 2.46 \\
\hline & & 3.19 & 3.63 & 3.74 & 3.52 & 2.89 & 2.90 & 2.94 & 2.91 \\
\hline & & 4.10 & 4.50 & 4.55 & 4.38 & 3.88 & 4.09 & 4.02 & 3.99 \\
\hline \multicolumn{2}{|c|}{ Mean } & 3.28 & 3.63 & 3.64 & 3.52 & 3.05 & 3.14 & 3.18 & 3.12 \\
\hline \multirow{3}{*}{10} & \multirow{3}{*}{$\begin{array}{c}0.0 \\
60 / 15 / 24 \\
120 / 30 / 48\end{array}$} & 3.18 & 3.58 & 3.40 & 3.39 & 3.28 & 3.29 & 3.34 & 3.30 \\
\hline & & 3.93 & 4.14 & 4.28 & 4.12 & 4.20 & 4.35 & 4.34 & 4.30 \\
\hline & & 4.88 & 5.45 & 5.20 & 5.18 & 4.48 & 4.57 & 4.59 & 4.55 \\
\hline \multicolumn{2}{|c|}{ Mean } & 3.99 & 4.39 & 4.29 & 4.20 & 3.99 & 4.07 & 4.09 & 4.05 \\
\hline \multirow{3}{*}{20} & \multirow{3}{*}{$\begin{array}{c}0.0 \\
60 / 15 / 24 \\
120 / 30 / 48\end{array}$} & 3.62 & 3.63 & 3.80 & 3.68 & 4.04 & 4.03 & 4.06 & 4.04 \\
\hline & & 4.30 & 4.58 & 4.36 & 4.41 & 4.61 & 4.71 & 4.78 & 4.70 \\
\hline & & 5.21 & 5.45 & 5.35 & 5.34 & 5.34 & 5.13 & 5.52 & 5.33 \\
\hline \multicolumn{2}{|c|}{ Mean } & 4.38 & 4.55 & 4.51 & 4.48 & 4.67 & 4.63 & 4.79 & 4.70 \\
\hline \multirow{3}{*}{30} & \multirow{3}{*}{$\begin{array}{c}0.0 \\
60 / 15 / 24 \\
120 / 30 / 48\end{array}$} & 4.21 & 5.32 & 5.13 & 4.88 & 4.49 & 4.51 & 4.58 & 4.53 \\
\hline & & 5.59 & 5.43 & 5.70 & 5.57 & 5.11 & 5.17 & 5.20 & 5.16 \\
\hline & & 5.84 & 5.70 & 5.43 & 5.67 & 5.37 & 5.45 & 5.53 & 5.45 \\
\hline \multicolumn{2}{|c|}{ Mean } & 5.21 & 5.48 & 5.42 & 5.37 & 4.99 & 5.05 & 5.11 & 5.05 \\
\hline \multirow{3}{*}{$\begin{array}{l}\text { Mean of } \\
\text { NPK }\end{array}$} & \multirow{3}{*}{$\begin{array}{c}0.0 \\
60 / 15 / 24 \\
120 / 30 / 48\end{array}$} & 3.39 & 3.82 & 3.74 & 3.65 & 3.54 & 3.57 & 3.64 & 3.58 \\
\hline & & 4.25 & 4.44 & 4.52 & 4.40 & 4.20 & 4.28 & 4.31 & 4.26 \\
\hline & & 5.01 & 5.27 & 5.13 & 5.14 & 4.77 & 4.81 & 4.91 & 4.83 \\
\hline \multicolumn{2}{|c|}{ Grand mean } & 4.22 & 4.51 & 4.46 & & 4.18 & 4.22 & 4.29 & \\
\hline
\end{tabular}

\begin{tabular}{|c|c|c|c|c|c|c|c|c|c|c|c|c|c|c|}
\hline L.S.D & A & B & C & AB & AC & BC & ABC & A & B & C & AB & AC & BC & ABC \\
\cline { 2 - 14 } & 0.34 & 0.58 & NS & 0.58 & NS & NS & NS & 0.07 & 0.07 & NS & 0.41 & NS & N.S & NS \\
\hline
\end{tabular}

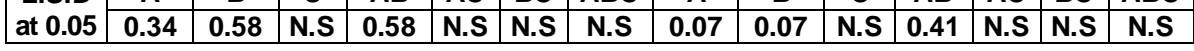

Concerning the effect of methods of micronutrients application, data show slight non-significant increases of wheat dry weight due to micronutrients additions in both seasons. 
Data show one significant interaction involving FYM and NPK. Other interactions were not significant. Only where no FYM was applied, addition of NPK caused significant increases which progressed with increased NPK. Under conditions of the highest FYM rate the increase was not progressive and both rates of $60 / 15 / 24$ and $120 / 30 / 48$ were similar. This shows that the high levels of organic manure contain enough amounts of $\mathrm{N}, \mathrm{P}$ and $\mathrm{K}$ needed for wheat plants at heading stage.

\section{Grain yield:}

Table 4 represents the effect of FYM, NPK and micronutrients application on grain yield of wheat. The main effect shows that grain yield was significantly and positively affected by manuring. Taking the average values into consideration, the increment was progressive with the increase in farmyard manure rate. The percentage of increase due to application of 10 , 20 and 30 ton/fed reached $49.0,91.7$ and $109.0 \%$, respectively in the first season; and 32.9, 76.6 and $122.7 \%$, respectively in the second year. Manure must have increased plant growth as shown by data at Table 3 which in turn contributed to the increase in grain yield. These results are in agreement with those obtained by Khalil and Aly (2004) and Ali, Maha (2007).

Table (4): Grain yield (ardab/fed) as affected by organic manure, NPK and micro-nutrients application.

\begin{tabular}{|c|c|c|c|c|c|c|c|c|c|}
\hline \multirow{3}{*}{$\begin{array}{c}\mathrm{FYM} \\
(\mathrm{A}) \\
\text { metric } \\
\text { ton/fed } \\
\end{array}$} & \multirow{3}{*}{$\begin{array}{c}\text { Rate of } \\
\mathrm{N} / \mathrm{P}_{2} \mathrm{O}_{5} / \mathrm{K}_{2} \mathrm{O} \\
(\mathrm{kg} / \mathrm{fed}) \\
\text { (B) }\end{array}$} & \multicolumn{8}{|c|}{ Micro-nutrients (C) } \\
\hline & & \multicolumn{4}{|c|}{ First season } & \multicolumn{4}{|c|}{ Second season } \\
\hline & & None & $\begin{array}{c}\text { Soil } \\
\text { appli. }\end{array}$ & $\begin{array}{l}\text { Foliar } \\
\text { appli. }\end{array}$ & None & $\begin{array}{c}\text { Control } \\
0.0\end{array}$ & $\begin{array}{c}\text { Soil } \\
\text { appli. }\end{array}$ & $\begin{array}{l}\text { Foliar } \\
\text { appli. }\end{array}$ & Mean \\
\hline \multirow{3}{*}{0.0} & \multirow{3}{*}{$\begin{array}{c}0.0 \\
60 / 15 / 24 \\
120 / 30 / 48 \\
\end{array}$} & 6.21 & 6.55 & 7.24 & 6.67 & 5.15 & 5.80 & 6.92 & 5.96 \\
\hline & & 7.10 & 7.47 & 8.03 & 7.54 & 7.00 & 7.38 & 7.80 & 7.39 \\
\hline & & 12.03 & 12.43 & 13.00 & 12.48 & 11.75 & 12.18 & 12.47 & 12.46 \\
\hline \multicolumn{2}{|c|}{ Mean } & 8.44 & 8.82 & 9.42 & 8.90 & 7.97 & 8.79 & 9.06 & 8.60 \\
\hline \multirow{3}{*}{10} & \multirow{3}{*}{$\begin{array}{c}0.0 \\
60 / 15 / 24 \\
120 / 30 / 48 \\
\end{array}$} & 9.86 & 10.36 & 11.16 & 10.46 & 8.85 & 8.95 & 10.05 & 9.28 \\
\hline & & 12.77 & 12.85 & 12.95 & 12.69 & 10.75 & 11.20 & 11.55 & 11.16 \\
\hline & & 16.08 & 16.92 & 16.98 & 16.62 & 13.32 & 13.93 & 14.27 & 13.84 \\
\hline \multicolumn{2}{|c|}{ Mean } & 12.90 & 13.38 & 13.50 & 13.26 & 10.97 & 11.36 & 11.96 & 11.43 \\
\hline \multirow{3}{*}{20} & \multirow{3}{*}{$\begin{array}{c}0.0 \\
60 / 15 / 24 \\
120 / 30 / 48 \\
\end{array}$} & 14.79 & 14.84 & 15 & 15.23 & 2 & 13.87 & 14.35 & 13.95 \\
\hline & & 15.69 & 16.24 & 17.58 & 16.50 & 14.50 & 15.10 & 15.23 & 14.94 \\
\hline & & 18.19 & 18.94 & 20.20 & 19.45 & 16.18 & 16.83 & 17.00 & 16.67 \\
\hline \multicolumn{2}{|c|}{ Mean } & 16.89 & 16.67 & 17.61 & 17.06 & 14.76 & 15.27 & 15.53 & 15.19 \\
\hline \multirow{3}{*}{30} & \multirow{3}{*}{$\begin{array}{c}0.0 \\
60 / 15 / 24 \\
120 / 30 / 48 \\
\end{array}$} & 16.34 & 16.97 & 17.24 & 16.52 & 17.63 & 18.20 & 18.33 & 18.05 \\
\hline & & 17.15 & 17.78 & 17.99 & 17.34 & 18.62 & 19.10 & 19.50 & 19.08 \\
\hline & & 20.92 & 20.94 & 22.08 & 21.32 & 20.10 & 20.25 & 20.67 & 20.34 \\
\hline \multicolumn{2}{|c|}{ Mean } & 18.13 & 18.56 & 19.10 & 18.60 & 18.78 & 19.18 & 19.50 & 19.15 \\
\hline \multirow{3}{*}{$\begin{array}{c}\text { Mean of } \\
\text { NPK }\end{array}$} & \multirow{3}{*}{$\begin{array}{c}0.0 \\
60 / 15 / 24 \\
120 / 30 / 48 \\
\end{array}$} & 11.80 & 12.18 & 12.67 & 12.22 & 11.31 & 11.70 & 12.41 & 11.01 \\
\hline & & 11.18 & 13.58 & 14.14 & 12.97 & 12.71 & 13.19 & 13.52 & 13.14 \\
\hline & & 16.80 & 17.31 & 18.06 & 17.39 & 15.33 & 15.80 & 16.10 & 15.74 \\
\hline \multicolumn{2}{|c|}{ Grand mean } & 14.09 & 14.36 & 14.75 & & 13.12 & 13.65 & 14.02 & \\
\hline
\end{tabular}

\begin{tabular}{|l|c|c|c|c|c|c|c|c|c|c|c|c|c|c|}
\hline L.S.D & A & B & C & AB & AC & BC & ABC & A & B & C & AB & AC & BC & ABC \\
\hline
\end{tabular}

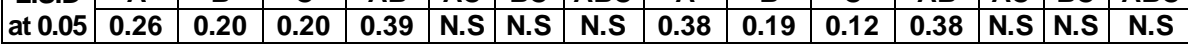

Grain yield was affected by NPK addition in both seasons. The percentage of increases of grain yield in the first season amounted to 6.1 and 
$42.3 \%$ due to applications of low (60/15/24) and high (120/30/48) doses of NPK, respectively. In the second season, the increases were 19.3 and $43.0 \%$ for low and high rates, respectively. N, P and $\mathrm{K}$ are the most important nutrients for the plants and in this sandy soil and their application showed marked positive effect. These data agree with Galal (2007) who stated that increasing levels of NPK led to a significant increase in the grain yield of wheat plants.

Concerning the effect of micronutrients, data reveal that micronutrients application either as soil or foliar applications caused in most cases significant increases in yield of grains. Foliar application surpassed soil application in its effect on grain yield by an average of about $3 \%$. The lower efficiency of soil application compared with foliar spraying may be due to reactions which convert available micronutrients to unavailable forms in the soil. These finding are in agreement with those obtained by Ismail et al, (2006) and Galal (2007).

With regard to the interactions effect, the only significant interaction was that between FYM and NPK, as occurred with dry weight of plant. The increase due to applying NPK at progressive rates was more marked in absence of FYM.

\section{Straw yield:}

Data presented in Table 5 reveal that, application of farmyard manure to wheat markedly increased straw yield. The main effect of manure showed percentage increase of straw yield upon applying 10, 20 and 30 ton/fed were 18.3, 26.6 and $34.6 \%$, respectively in the first season and 24.5 , 45.1 and $62.7 \%$, respectively in the second season. The difference between 10 and 20 ton FYM/fed was not significant in the first season only. Growth substances and available nutrients in FYM would enhance plant growth which in turn would increase plant growth. The current results are similar to those obtained by Khalil and Aly (2004).

Concerning NPK application, data show that values of straw yield of wheat plants averaged overall micronutrients application significantly responded to increasing NPK rate in both seasons. The maximum straw yield values were attained at highest dose of NPK (120/30/48). Such results could be due to increases in dry weight caused by increasing NPK levels. These results are in cope with those obtained by Galal (2007).

Application of micronutrients, either as soil application or as foliar spray increased straw yield in both seasons. Foliar spraying produced straw yield which surpassed that produced by soil application by 8.1 in the first season and $1.1 \%$ in the second season.

There was a significant interaction between FYM and NPK fertilization. The straw yield responded to increasing NPK levels only where no FYM was applied. Also, under high NPK rate, application of FYM was not effective; but in absence of NPK, addition of FYM caused increasd straw yield. 
Table (5): Straw yield (ton/fed) as affected by organic manure, NPK and micro-nutrients application.

\begin{tabular}{|c|c|c|c|c|c|c|c|c|c|}
\hline \multirow{3}{*}{$\begin{array}{c}\text { FYM } \\
(A) \\
\text { metric } \\
\text { ton/fed } \\
\end{array}$} & \multirow{3}{*}{ 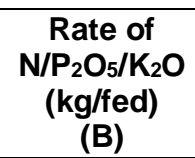 } & \multicolumn{8}{|c|}{ Micro-nutrients (C) } \\
\hline & & \multicolumn{4}{|c|}{ First season } & \multicolumn{4}{|c|}{ Second season } \\
\hline & & None & $\begin{array}{r}\text { Soil } \\
\text { appli }\end{array}$ & $\begin{array}{l}\text { Foliar } \\
\text { appli. }\end{array}$ & Mean & None & \begin{tabular}{|c|} 
Soil \\
appli.
\end{tabular} & $\begin{array}{l}\text { Foliar } \\
\text { appli. }\end{array}$ & Mean \\
\hline \multirow{3}{*}{0.0} & \multirow{3}{*}{$\begin{array}{c}0.0 \\
60 / 15 / 24 \\
120 / 30 / 48\end{array}$} & 1.90 & 2.05 & 2.46 & 2.14 & 1.63 & 1.65 & 1.79 & 1.65 \\
\hline & & \begin{tabular}{|l|}
2.17 \\
\end{tabular} & 2.42 & 2.39 & 2.33 & 11 & 2.19 & 2.24 & 18 \\
\hline & & 3.23 & 3.40 & 3.68 & 3.44 & 2.19 & 2.25 & 2.32 & 2.25 \\
\hline \multirow{4}{*}{10} & Mean & \begin{tabular}{|l|}
2.43 \\
\end{tabular} & 2.62 & 2.84 & 2.63 & 1.97 & 2.03 & 2.11 & 2.04 \\
\hline & \multirow{3}{*}{$\begin{array}{c}0.0 \\
60 / 15 / 24 \\
120 / 30 / 48 \\
\end{array}$} & \begin{tabular}{|l|}
2.57 \\
\end{tabular} & 3.04 & 3.11 & 2.90 & 2.30 & 2.46 & 2.47 & 2.43 \\
\hline & & 2.66 & 2.69 & 3.82 & 3.06 & 2.41 & 2.57 & 2.57 & 2.55 \\
\hline & & \begin{tabular}{|l|}
3.04 \\
\end{tabular} & 4.00 & 4.12 & 3.27 & 2.51 & 2.76 & 2.79 & 2.76 \\
\hline \multicolumn{2}{|r|}{ Mean } & 2.76 & 3.24 & 3.32 & 3.11 & 2.41 & 2.59 & 2.61 & 2.54 \\
\hline \multirow{3}{*}{20} & \multirow{3}{*}{$\begin{array}{c}0.0 \\
60 / 15 / 24 \\
120 / 30 / 48\end{array}$} & 2.79 & 3.23 & 3.28 & 3.10 & 2.57 & 2.99 & 2.92 & 2.90 \\
\hline & & 3.00 & 2.99 & 3.41 & 3.13 & 2.91 & 2.95 & 2.99 & 2.95 \\
\hline & & \begin{tabular}{|l|}
3.44 \\
\end{tabular} & 3.64 & 4.14 & 3.74 & 2.98 & 3.11 & 3.20 & 3.09 \\
\hline \multicolumn{2}{|r|}{ Mean } & 3.08 & 3.29 & 3.61 & 3.33 & 2.82 & 3.02 & 3.04 & 2.96 \\
\hline \multirow{3}{*}{30} & \multirow{3}{*}{$\begin{array}{c}0.0 \\
60 / 15 / 24 \\
120 / 30 / 48\end{array}$} & 3.38 & 3.41 & 3.46 & 3.41 & 3.17 & 3.27 & 3.28 & 2.21 \\
\hline & & 3.43 & 3.49 & 3.56 & 3.46 & 3.26 & 3.39 & 3.32 & 3.29 \\
\hline & & 3.54 & 3.76 & 3.64 & 3.65 & 3.36 & 3.39 & 3.41 & 3.40 \\
\hline \multicolumn{2}{|r|}{ Mean } & 3.45 & 3.55 & 3.62 & 3.54 & 3.26 & 3.35 & 3.36 & 3.32 \\
\hline \multirow{3}{*}{$\begin{array}{c}\text { Mean of } \\
\text { NPK }\end{array}$} & \multirow{4}{*}{$\begin{array}{c}0.0 \\
60 / 15 / 24 \\
120 / 30 / 48 \\
d \text { mean }\end{array}$} & 2.66 & 2.93 & 3.08 & 2.89 & 2.42 & 2.59 & 2.61 & 2.54 \\
\hline & & 2.81 & 2.90 & 3.29 & 3.00 & 2.67 & 2.77 & 2.78 & 2.74 \\
\hline & & \begin{tabular}{|l|}
3.31 \\
\end{tabular} & 3.71 & 3.90 & 3.64 & 2.76 & 2.88 & 2.93 & 2.86 \\
\hline Gra & & 2.91 & 3.20 & 3.46 & & 2.62 & 2.75 & 2.78 & \\
\hline
\end{tabular}

\begin{tabular}{|l|c|c|c|c|c|c|c|c|c|c|c|c|c|c|}
\hline L.S.D & A & B & C & AB & AC & BC & ABC & A & B & C & AB & AC & BC & ABC \\
\hline
\end{tabular}

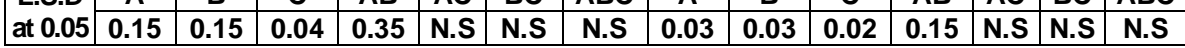

\section{Nitrogen, phosphorus and potassium use efficiency:}

Data presented in Tables 6 to 8 show the effect of organic manure, NPK and methods of micronutrients on the nutrient use efficiency for N, P and $\mathrm{K}$. Increasing farmyard manure levels to more than 10 metric ton/fed gave a decrease in N-use efficiency (NUE) in the first season. However with no manuring or with addition of 10 ton FYM/fed in the second season NUE was highest. This means that in the second season under 0 and 20 ton FYM/fed, each $\mathrm{kg}$ of $\mathrm{N}$ produced $5.76,5.19 \mathrm{~kg}$ grains, and then these values decreased as FYM increases up to 20 and 30 ton/fed. These results are in harmony with those obtained by Atia and Aly (1998).

Nitrogen use efficiency (NUE) gradually increased as NPK rate increased. The increase in nitrogen use efficiency by grains due to NPK at $120 / 30 / 48$ was $76.2 \%$ in the first season and $48.3 \%$ in the second one as compared over that obtained with 60/15/24. The response of grain yield to the high NPK level of 120/30/48 reflect the importance of nitrogen.

Concerning P-use efficiency (PUE) and K-use efficiency (KUE), Table 7 show that in the first season values such parameters were significantly increased with increasing the rate of the applied nutrients either in the form of mineral fertilizer or FYM. In the second season, however these 
values increased with increasing levels of applied mineral fertilizer. However, FYM decreased such values. Such results could be ascribed to the higher contents of $\mathrm{P}$ or $\mathrm{K}$ in higher doses of FYM which exceeded than plants requirement and consequently values of PUE and KUE were decreased.

Table (6): NUE (kg grains/kg N) as affected by organic manure, NPK and micro-nutrients application.

\begin{tabular}{|c|c|c|c|c|c|c|c|c|c|}
\hline \multirow{3}{*}{$\begin{array}{c}\text { FYM } \\
\text { (A) } \\
\text { metric } \\
\text { ton/fed }\end{array}$} & \multirow{3}{*}{$\begin{array}{c}\text { Rate of } \\
\mathrm{N}^{2} \mathrm{P}_{2} \mathrm{O}_{5} / \mathrm{K}_{2} \mathrm{O} \\
(\mathrm{kg} / \mathrm{fed}) \\
\text { (B) }\end{array}$} & \multicolumn{8}{|c|}{ Micro-nutrients (C) } \\
\hline & & \multicolumn{4}{|c|}{ First season } & \multicolumn{4}{|c|}{ Second season } \\
\hline & & None & $\begin{array}{r}\text { Soil } \\
\text { appli. }\end{array}$ & $\begin{array}{l}\text { Foliar } \\
\text { appli. }\end{array}$ & Mean & None & $\begin{array}{l}\text { Soil } \\
\text { appli. }\end{array}$ & $\begin{array}{l}\text { Foliar } \\
\text { appli. }\end{array}$ & Mean \\
\hline \multirow{3}{*}{0.0} & \multirow{3}{*}{$\begin{array}{c}0.0 \\
60 / 15 / 24 \\
120 / 30 / 48\end{array}$} & - & - & - & - & - & - & - & - \\
\hline & & 2.24 & 2.30 & 1.98 & 2.18 & 4.62 & 3.99 & 2.37 & 3.66 \\
\hline & & 7.25 & 3.34 & 6.64 & 7.08 & 7.50 & 9.21 & 6.93 & 7.88 \\
\hline \multicolumn{2}{|c|}{ Mean } & 4.74 & 4.82 & 4.31 & 4.62 & 6.06 & 6.60 & 4.65 & 5.78 \\
\hline \multirow{3}{*}{10} & \multirow{3}{*}{$\begin{array}{c}0.0 \\
60 / 15 / 24 \\
120 / 30 / 48 \\
\end{array}$} & - & - & - & - & - & - & - & - \\
\hline & & 7.26 & 6.23 & 3.21 & 5.57 & 4.62 & 5.63 & 3.75 & 4.67 \\
\hline & & 8.37 & 8.18 & 5.84 & 7.46 & 5.60 & 6.21 & 5.28 & 5.70 \\
\hline \multicolumn{2}{|r|}{ Mean } & 7.55 & 7.2 & 4.52 & 6.42 & 5.12 & 5.91 & 4.52 & 5.19 \\
\hline \multirow{3}{*}{20} & \multirow{3}{*}{$\begin{array}{c}0.0 \\
60 / 15 / 24 \\
120 / 30 / 48 \\
\end{array}$} & - & - & - & - & - & - & - & - \\
\hline & & 3.21 & 5.87 & 5.90 & 5.00 & 2.39 & 2.81 & 1.94 & 2.37 \\
\hline & & 5.45 & 5.25 & 4.50 & 5.73 & 3.18 & 3.69 & 3.32 & 3.39 \\
\hline \multicolumn{2}{|c|}{ Mean } & 4.32 & 5.55 & 6.20 & 5.36 & 2.79 & 3.26 & 2.63 & 2.88 \\
\hline \multirow{3}{*}{30} & \multirow{3}{*}{$\begin{array}{c}0.0 \\
60 / 15 / 24 \\
120 / 30 / 48\end{array}$} & - & - & - & - & - & - & - & - \\
\hline & & 1.88 & 2.52 & 2.00 & 2.13 & 2.31 & 2.69 & 2.79 & 2.60 \\
\hline & & 5.66 & 4.95 & 7.29 & 5.97 & 2.69 & 3.00 & 2.75 & 2.79 \\
\hline \multicolumn{2}{|r|}{ Mean } & 3.77 & 3.74 & 4.64 & 4.05 & 2.51 & 2.82 & 2.78 & 2.70 \\
\hline \multirow{3}{*}{$\begin{array}{c}\text { Mean of } \\
\text { NPK }\end{array}$} & \multirow{3}{*}{$\begin{array}{c}0.0 \\
60 / 15 / 24 \\
120 / 30 / 48\end{array}$} & - & - & - & - & - & - & - & - \\
\hline & & 3.65 & 4.23 & 3.27 & 3.72 & 3.48 & 3.78 & 2.72 & 3.33 \\
\hline & & 6.68 & 6.44 & 6.57 & 6.56 & 4.74 & 5.52 & 4.58 & 4.94 \\
\hline \multicolumn{2}{|c|}{ Grand mean } & 5.10 & 5.33 & 4.92 & & 4.11 & 4.65 & 3.65 & \\
\hline
\end{tabular}

\begin{tabular}{|l|c|c|c|c|c|c|c|c|c|c|c|c|c|c|}
\hline L.S.D & A & B & C & AB & AC & BC & ABC & A & B & C & AB & AC & BC & ABC \\
\cline { 2 - 9 }
\end{tabular}

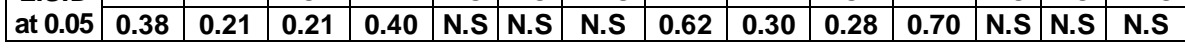

Regarding micronutrients, data in the same Tables demonstrated that micronutrients added as soil application recorded higher N, P or K use efficiency in the two studied seasons. The lower NUE of the no-micronutrient on to foliar application of micronutrients as compared with soil application amounted to 0.23 and $0.41 \mathrm{~kg}$ grains $/ \mathrm{kg} \mathrm{N}$ in the first season, respectively. The corresponding values in the second season were 0.54 and $1.00 \mathrm{~kg}$ grains $/ \mathrm{kg} \mathrm{N}$. The same trend was obtained for $\mathrm{P}$ and $\mathrm{K}$ use efficiency.

The highest NUE was obtained for plants fertilized with NPK of $(120 / 30 / 48)+10$ metric ton FYM/fed in the first seasons; or NPK of (60/15/24) with no FYM application in the second season.

It could concluded that the addition of FYM at rate of 30 metric ton/fed, high NPK dose (120/30/48) and micronutrients as foliar application to wheat plant grown in sand soil produced high dry weight as well as grains and straw yields. 
Table (7): PUE (kg grains/kg P) as affected by organic manure, NPK and micro-nutrients application.

\begin{tabular}{|c|c|c|c|c|c|c|c|c|c|}
\hline \multirow{3}{*}{$\begin{array}{c}\text { FYM } \\
(\mathrm{A}) \\
\text { metric } \\
\text { ton/fed }\end{array}$} & \multirow{3}{*}{$\begin{array}{c}\text { Rate of } \\
\mathrm{N} / \mathrm{P}_{2} \mathrm{O}_{5} / \mathrm{K}_{2} \mathrm{O} \\
(\mathrm{kg} / \mathrm{fed}) \\
\text { (B) }\end{array}$} & \multicolumn{8}{|c|}{ Micro-nutrients (C) } \\
\hline & & \multicolumn{4}{|c|}{ First season } & \multicolumn{4}{|c|}{ Second season } \\
\hline & & None & $\begin{array}{c}\text { Soil } \\
\text { appli. }\end{array}$ & $\begin{array}{l}\text { Foliar } \\
\text { appli. }\end{array}$ & Mean & None & $\begin{array}{c}\text { Soil } \\
\text { appli. }\end{array}$ & $\begin{array}{l}\text { Foliar } \\
\text { appli. }\end{array}$ & Mean \\
\hline \multirow{3}{*}{0.0} & \multirow{3}{*}{$\begin{array}{c}0.0 \\
60 / 15 / 24 \\
120 / 30 / 48\end{array}$} & - & - & - & - & - & - & - & - \\
\hline & & 8.88 & 9.17 & 7.92 & 8.66 & 18.50 & 15.75 & 8.75 & 14.33 \\
\hline & & 29.01 & 29.40 & 28.82 & 29.07 & 33.00 & 36.87 & 27.74 & 32.54 \\
\hline \multicolumn{2}{|c|}{ Mean } & 18.95 & 19.29 & 18.38 & 18.87 & 25.74 & 26.37 & 18.24 & 23.44 \\
\hline \multirow{3}{*}{10} & \multirow{3}{*}{$\begin{array}{c}0.0 \\
60 / 15 / 24 \\
120 / 30 / 48\end{array}$} & - & - & - & - & - & - & - & - \\
\hline & & 29.10 & 24.90 & 12.87 & 22.23 & 18.50 & 22.49 & 15.00 & 18.66 \\
\hline & & 31.13 & 32.75 & 28.59 & 30.83 & 18.62 & 24.87 & 21.12 & 21.54 \\
\hline \multicolumn{2}{|r|}{ Mean } & 30.12 & 28.83 & 20.73 & 26.57 & 15.56 & 23.69 & 18.06 & 20.10 \\
\hline \multirow{3}{*}{20} & \multirow{3}{*}{$\begin{array}{c}0.0 \\
60 / 15 / 24 \\
120 / 30 / 48\end{array}$} & - & - & - & - & - & - & - & - \\
\hline & & 12.87 & 23.49 & 23.19 & 19.85 & 8.75 & 12.24 & 8.75 & 9.92 \\
\hline & & 22.20 & 21.17 & 26.00 & 23.12 & 12.75 & 14.75 & 14.49 & 14.00 \\
\hline \multicolumn{2}{|c|}{ Mean } & 17.69 & 22.34 & 24.60 & 21.48 & 10.76 & 13.50 & 11.63 & 12.00 \\
\hline \multirow{3}{*}{30} & \multirow{3}{*}{$\begin{array}{c}0.0 \\
60 / 15 / 24 \\
120 / 30 / 48\end{array}$} & - & - & - & - & - & - & - & - \\
\hline & & 7.50 & 8.07 & 8.48 & 8.01 & 9.99 & 7.65 & 11.75 & 9.80 \\
\hline & & 22.64 & 19.82 & 29.18 & 23.88 & 12.38 & 10.25 & 11.75 & 11.46 \\
\hline \multicolumn{2}{|c|}{ Mean } & 15.08 & 13.95 & 18.83 & 15.95 & 11.19 & 9.00 & 11.75 & 10.64 \\
\hline \multirow{3}{*}{$\begin{array}{c}\text { Mean of } \\
\text { NPK }\end{array}$} & \multirow{3}{*}{$\begin{array}{c}0.0 \\
60 / 15 / 24 \\
120 / 30 / 48\end{array}$} & - & - & - & - & - & - & - & - \\
\hline & & 14.60 & 16.41 & 13.11 & 14.72 & 13.94 & 14.54 & 11.06 & 13.17 \\
\hline & & 26.25 & 25.79 & 28.14 & 26.72 & 19.19 & 21.69 & 18.78 & 19.89 \\
\hline \multicolumn{2}{|c|}{ Grand mean } & 20.43 & 21.10 & 20.63 & & 16.56 & 18.12 & 14.93 & \\
\hline
\end{tabular}

\begin{tabular}{|l|c|c|c|c|c|c|c|c|c|c|c|c|c|c|}
\hline L.S.D & A & B & C & AB & AC & BC & ABC & A & B & C & AB & AC & BC & ABC \\
\hline
\end{tabular}

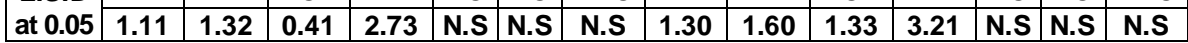

Table (8): KUE (kg grains/kg K) as affected by organic manure, NPK and micro-nutrients application.

\begin{tabular}{|c|c|c|c|c|c|c|c|c|c|}
\hline \multirow{3}{*}{$\begin{array}{c}\text { FYM } \\
(\mathrm{A}) \\
\text { metric } \\
\text { ton/fed }\end{array}$} & \multirow{3}{*}{$\begin{array}{c}\text { Rate of } \\
\mathrm{N} / \mathrm{P}_{2} \mathrm{O}_{5} / \mathrm{K}_{2} \mathrm{O} \\
\text { (kg/fed) } \\
\text { (B) }\end{array}$} & \multicolumn{8}{|c|}{ Micro-nutrients (C) } \\
\hline & & \multicolumn{4}{|c|}{ First season } & \multicolumn{4}{|c|}{ Second season } \\
\hline & & None & $\begin{array}{l}\text { Soil } \\
\text { appli. }\end{array}$ & $\begin{array}{l}\text { Foliar } \\
\text { appli. }\end{array}$ & Mean & None & $\begin{array}{l}\text { Soil } \\
\text { appli. }\end{array}$ & $\begin{array}{l}\text { Foliar } \\
\text { appli. }\end{array}$ & Mean \\
\hline \multirow{3}{*}{0.0} & \multirow{3}{*}{$\begin{array}{c}0.0 \\
60 / 15 / 24 \\
120 / 30 / 48\end{array}$} & - & - & - & - & - & - & - & - \\
\hline & & 5.54 & 5.73 & 4.89 & 5.40 & 11.76 & 9.84 & 5.46 & 9.02 \\
\hline & & 18.12 & 18.36 & 18.12 & 18.20 & 20.61 & 23.04 & 17.34 & 20.33 \\
\hline \multirow{4}{*}{10} & Mean & 11.84 & 12.05 & 11.54 & 11.81 & 16.19 & 16.44 & 11.40 & 14.67 \\
\hline & \multirow{3}{*}{$\begin{array}{c}0.0 \\
60 / 15 / 24 \\
120 / 30 / 48\end{array}$} & 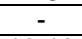 & - & - & - & - & - & - & - \\
\hline & & 18.18 & 15.56 & 8.04 & 13.92 & 11.57 & 14.06 & 9.38 & 11.67 \\
\hline & & 19.46 & 12.69 & 10.10 & 14.09 & 14.15 & 15.54 & 13.20 & 14.30 \\
\hline \multicolumn{2}{|r|}{ Mean } & 18.83 & 14.13 & 9.08 & 14.01 & 12.86 & 14.81 & 11.30 & 12.99 \\
\hline \multirow{3}{*}{20} & \multirow{3}{*}{$\begin{array}{c}0.0 \\
60 / 15 / 24 \\
120 / 30 / 48 \\
\end{array}$} & 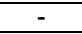 & 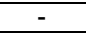 & 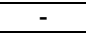 & 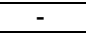 & - & - & - & - \\
\hline & & 11.93 & 14.54 & 16.02 & 14.16 & 5.46 & 7.65 & 5.46 & 6.20 \\
\hline & & 13.67 & 15.48 & 9.38 & 12.84 & 8.00 & 9.21 & 8.28 & 8.49 \\
\hline \multicolumn{2}{|r|}{ ean } & 12.80 & 15.02 & 12.71 & 13.50 & 6.72 & 8.43 & 6.87 & 7.35 \\
\hline \multirow{3}{*}{30} & \multirow{3}{*}{$\begin{array}{c}0.0 \\
60 / 15 / 24 \\
120 / 30 / 48\end{array}$} & - & - & - & - & - & - & - & - \\
\hline & & 5.43 & 4.70 & 8.40 & 6.20 & 6.24 & 5.63 & 7.34 & 6.41 \\
\hline & & 20.94 & 24.93 & 22.64 & 22.83 & 7.73 & 6.41 & 7.34 & 7.16 \\
\hline \multicolumn{2}{|r|}{ Mean } & 13.19 & 14.84 & 15.53 & 14.52 & 6.99 & 6.02 & 7.34 & 6.78 \\
\hline \multirow{3}{*}{$\begin{array}{l}\text { Mean of } \\
\text { NPK }\end{array}$} & \multirow{3}{*}{$\begin{array}{c}0.0 \\
60 / 15 / 24 \\
120 / 30 / 48\end{array}$} & 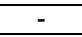 & - & - & - & - & - & - & - \\
\hline & & 10.28 & 10.14 & 9.35 & 9.92 & 8.76 & 9.30 & 6.92 & 8.33 \\
\hline & & 18.05 & 17.87 & 15.06 & 16.98 & 12.62 & 13.55 & 11.54 & 12.57 \\
\hline \multicolumn{2}{|c|}{ Grand mean } & 14.16 & 14.01 & 12.21 & & 10.70 & 11.43 & 9.23 & \\
\hline
\end{tabular}

\begin{tabular}{|c|c|c|c|c|c|c|c|c|c|c|c|c|c|c|}
\hline L.S.D & A & B & C & AB & AC & BC & ABC & A & B & C & AB & AC & BC & ABC \\
\hline
\end{tabular}

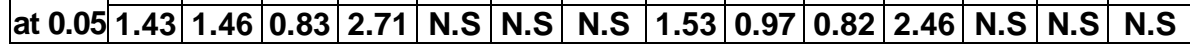




\section{REFERENCES}

Ali, Maha, M.E. (2007). Growth of wheat plant on a light textured soil as influenced by water stress and some soil conditioners. M.Sc. Thesis, Fac. of Agric., Benha Univ., Egypt.

Abd El-Hafeez, A.M. (2004). Effect of certain sulfur and nitrogen treatments on some nutrients availability and plant growth. M.Sc. Thesis, Fac. of Agric. Al-Azhar Univ. Egypt.

Abd El-Maksoud, M.F. (2002). Response of some wheat cultivars to biofertilizer and nitrogen levels. Zagazig J. Agric. Res., 29: 891-905.

Atia, N.A. and Aly, R.M. (1998). Effect of different levels of nitrogen and phosphorus fertilizers with the application of rabbit manure on yield potentiality of wheat in sand soils. Zagazig J.Agric. Res.,25(4):595-617.

Balyan, J.S. (1992). Effect of organic recycling on yield attributes, nitrogen concentration and uptake in wheat (Triticum aestivum). India J. Agron. 37: 701-704.

Craswell, E.T. and Godwin, D.C. (1984). The efficiency of nitrogen fertilizers applied to cereals in different climates. Adv. Plant Nutrition, 1: 1-55.

El-Afandy, K.T.H. (1995). Physiological response of wheat under different levels of organic matter and nitrogen fertilization and its effect on yield and grain quality in South of Sinai. Ph.D. Thesis, Fac. of Agric., Ain Shams Univ., Egypt.

El-Bana, A.Y.A. (2000). Effect of seedling rates and PK fertilizer levels on grain yield and yield attributes of wheat under newly cultivated sandy soil conditions. Zagazig J. Agric. Res., 27: 1161-1178.

El-Ghamry, A.M. and El-Naggar, E.M. (2001). Evaluation of some organic residues as soil conditioners on different Egyptian soils. J. Agric. Sci., Mansoura Univ., 26: 8207-8214.

El-Yamani, M.S. (2003). Influence of different regime and potassium fertilization levels on yield and yield components of four wheat cultivars. J. Agric. Sci., Mansoura Univ., 28: 8507-8520.

Galal, O.A.M. (2007). Studies on balanced fertilization of wheat plant. Ph.D. Thesis, Fac. of Agric., Benha Univ., Egypt.

Ismail, S.A.; Morsy, A.A.; Omran, M.M. and Foaad, M.M. (2006). Wheat grain and straw yields, grain quality and some nutrients uptake as affected by nitrogen sources and levels under zinc application. The Second Conference on Farm Integrated Pest Management, 16-18 Jan.

Khalil, F.A. and Aly, S.A. (2004). Effect of organic fertilizers as substitutions of mineral nitrogen fertilizer applied at planting on yield and quality of wheat. Minufiya J. Agric. Res., 2: 435-449.

Klute (1986). Methods of Analysis. $2^{\text {nd }}$ Edition Part 1: Physical and Mineralogical Methods. American Society of Agronomy, Mudison, Wisconsin, USA.

Mowafy, S.A.E. (2002). Effect of organic manuring and splitting of different levels of nitrogen on wheat under sprinkler irrigation in sandy soils. Zagazig J. Agric. Res., 29: 51-72. 
Page, A.L.; Miller, R.H. and Keeny, D.R. (1982). Methods of Soil Analysis. $2^{\text {nd }}$ Edition Part 2: Chemical and Microbiological Properties. American Society of Agronomy, Madisons, Wisconsin, USA.

Sakr, A.A.; Rizk, S.A. and El-Sebaay, A.S. (1992). Effect of organic manures on plant growth and NPK uptake by wheat and maize plants. Egypt J. Soil Sci., 32(2): 249-263.

Shrivastava, G.R.; Lakpale, R.; Verma, A.K.; Choubey, N.K.; Singh, A.P. and Joshi, B.S. (2003). Effect of farmyard manure, phosphorus and zinc on black gram (Phaseoulus mungo) - wheat (Triticum aestivm) cropping sequence under Vertisols of Chhattisgarh plains Indian J. of Agric. Sci., 73: 72-84.

Shams El-Din, H.A.I. (1993). Application methods and rates of some micronutrients on wheat plant. Ph.D. Thesis, Fac. of Agric., El-Mansoura Univ., Egypt.

Snedecor, G.W. and Cochran W.G. (1980). "Statistical Methods" $7^{\text {th }}$ Edin. lowa State Univ., Press, lowa, USA.

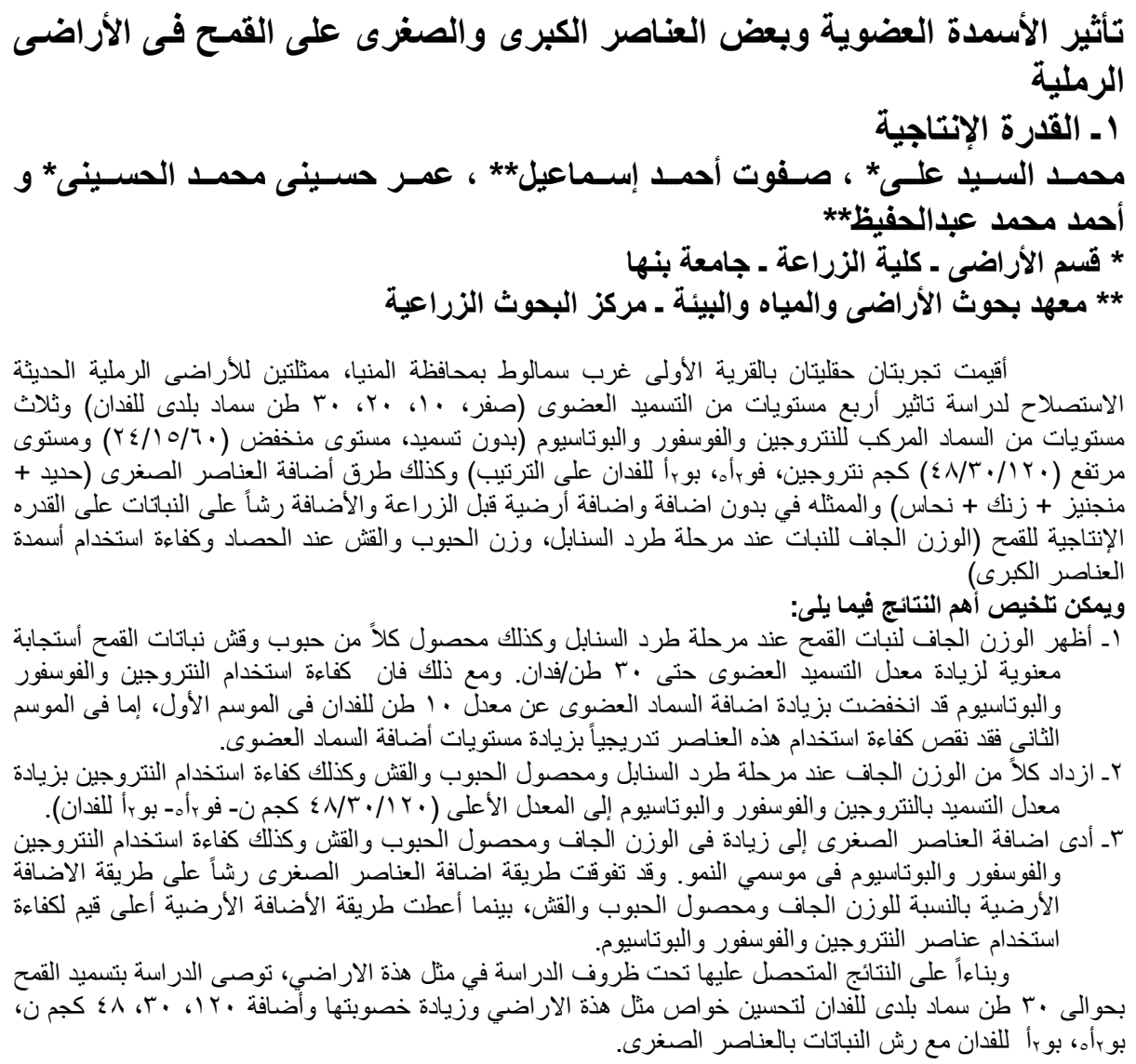

